\title{
Nitrogen fertilization effects on wheat blast epidemics under varying field environmental conditions
}

\author{
Sérgio R. Silva ${ }^{1}$ (D) - Adriano A. P. Custódio ${ }^{2} \cdot$ José S. S. Foloni $^{3} \cdot$ Edner Betioli-Junior $^{4} \cdot$ Manoel C. Bassoi $^{3}$
}

Received: 31 July 2018 / Accepted: 22 April 2019 / Published online: 15 May 2019

(C) Sociedade Brasileira de Fitopatologia 2019

\begin{abstract}
Wheat blast, caused by the fungus Magnaporthe oryzae Triticum (MoT) pathotype, is one of the most important yield-reducing diseases of wheat, mainly in the tropical wheat-growing regions of South America. In this study, we assessed the effects of nitrogen $(\mathrm{N})$ fertilization on wheat blast epidemics. Factorial experiments were carried out in Londrina (2015 and 2016) and Floresta (two sowings in 2017) with $\mathrm{N}$ rates $(0,40,80$ and $120 \mathrm{~kg} / \mathrm{ha}$ for the first experiment, and 0,60 and $120 \mathrm{~kg} / \mathrm{ha}$ for the second) and wheat genotypes (three and six cultivars, for the first and second experiments, respectively) as factors. Wheat blast on spikes occurred only in two out of four experiments: 2015 in Londrina and first sowing of 2017 in Floresta. Nitrogen increased blast severity in the first crop of 2017 in Floresta, where blast severity on spikes ranged from 10 to $94 \%$ and yield ranged from 47 to $2823 \mathrm{~kg} / \mathrm{ha}$, depending on $\mathrm{N}$ rate and genotype. Nitrogen did not affect wheat blast (except for genotype S1) in the 2015 Londrina trial, where blast severity on spikes ranged from 16.9 to $36.8 \%$. Differences in blast severity among genotypes were likely due to different crop heading periods. Our results suggest that $\mathrm{N}$ fertilization and sowing time should be considered in a management strategy for reducing the risk of wheat blast epidemics.
\end{abstract}

Keywords Magnaporthe oryzae $\cdot$ Pyricularia oryzae $\cdot$ Triticum aestivum $\cdot$ Plant nutrition

\section{Introduction}

Wheat blast, caused by the hemibiotrophic fungus Magnaporthe oryzae Triticum (MoT) pathotype (anamorph: Pyricularia oryzae), is one of the most important yieldreducing diseases of wheat (Triticum aestivum) in the tropical, and eventually in subtropical wheat-growing regions of Brazil, Bolivia, Paraguay and Argentina (Kohli et al. 2011; Cruz and Valent 2017; Rodrigues et al. 2017). This disease has limited wheat expansion to several regions that are suitable for wheat cropping in the tropics. Recently, wheat blast

Section Editor: Leandro J. Dallagnol

Sérgio R. Silva

sergio.ricardo@embrapa.br

Embrapa Trigo, Passo Fundo, RS 99050-970, Brazil

Instituto Agronômico do Paraná, Londrina, PR 86057-970, Brazil

Embrapa Soja, Londrina, PR 86001-970, Brazil

4 COCAMAR Cooperativa Agroindustrial, Maringá, PR 87065-590, Brazil emerged for the first time in Asia (Bangladesh), where it has been considered a major threat to wheat production in Asia (Callaway 2016; Sadat and Choi 2017).

The fungus infects the plant, after wheat heads are emerged, through the rachis of the spikes. The disease develops to severe levels at warmer temperatures $\left(18\right.$ to $28{ }^{\circ} \mathrm{C}$ ), high relative humidity (>90\%), extended periods of dew or rain $(>15 \mathrm{~h})$ and cloudy days (Lima 2004; Cruz et al. 2009; Kohli et al. 2011). Severe epidemics may lead to yield losses of up to $74 \%$ (Goulart et al. 2007) due to damage in the rachis that affects the translocation of nutrients and photosynthates to grains and may cause premature death of spike above the infection site (Cruz and Valent 2017; Rodrigues et al. 2017).

Currently, commercial wheat cultivars do not posses satisfactory levels of genetic resistance to wheat blast, especially during disease-inducing weather conditions. Because fungicides provide only modest and inconsistent results (Goulart et al. 2007; Cruz and Valent 2017) there is great uncertainty on how to effectively control the disease. According to the literature, the effect of nitrogen $(\mathrm{N})$ fertilization on plant disease severity can be either positive or negative varying with the pathosystem. In a meta-analysis study of 57 scientific articles to summarize the effect of mineral fertilization on diseases, 
authors found that $\mathrm{N}$ fertilization tends to increase susceptibility of plants to hemibiotrophic fungal pathogens (Veresoglou et al. 2013). The amount of available $\mathrm{N}$ for the plant may have a pronounced and contradictory effect on disease expression (Huber and Thompson 2007). For instance, while severity of cereal rust (Puccinia graminis), wheat mildew (Erysiphe graminis) and rice blast (Magnaporthe oryzae) was greater with the increase of $\mathrm{N}$ rates, wheat tan spot (Pyrenophora tritici-repentis), wheat stagonospora nodorum blotch (Stagonospora nodorum) and cereal take-all (Gaeumannomyces graminis) have been consistently reduced in response to increasing $\mathrm{N}$ rates. Moreover, plant susceptibility to these diseases is associated with increases in certain free amino acids available for pathogen nutrition in infected tissues. However, increasing host resistance can be due to decrease of peptidase activity and reduced availability of some amino acids needed for pathogen nutrition (Huber and Thompson 2007). According to Mur et al. (2016) the use of $\mathrm{NO}_{3}{ }^{-}$or $\mathrm{NH}_{4}{ }^{+}$fertilizers affects the outcome of plantpathogen interaction, being the effects associated with host resistance and susceptibility, respectively. Metabolically, $\mathrm{NO}_{3}{ }^{-}$increases production of polyamines (e.g. spermine and spermidine), which are established defense signals, and $\mathrm{NH}_{4}{ }^{+}$ augments $\gamma$-aminobutyric acid (GABA) levels, which may be a nutrient source for the pathogen.

Information on the effect of $\mathrm{N}$ fertilization on wheat blast epidemics in the field, particularly its interaction with wheat genotypes, is not available. Since N is widely used in great amount by wheat growers to maximize yield, such knowledge is key for improving wheat blast management. The objective of this study was to evaluate the interaction effect of $\mathrm{N}$ fertilization rates and wheat genotypes on blast severity on spikes under varying field environmental conditions across years, locations and sowing dates.

\section{Material and methods}

\section{Experimental setting 1, Londrina trials}

The first experimental setting was conducted in Londrina $\left(23^{\circ} 11^{\prime} 37^{\prime \prime} \mathrm{S}, 51^{\circ} 11^{\prime} 03^{\prime \prime} \mathrm{W}\right.$; altitude of $\left.628 \mathrm{~m}\right)$, Paraná State, southern Brazil, one in 2015 and the other in 2016 crop seasons. The climate of the region is humid subtropical, Cfa according to the Köppen classification (Köppen 1931). Daily meteorological variables (precipitation, temperature and relative humidity; Fig. 1) were recorded in an automatic weather station (equipped with: datalogger Campbell Scientific $\AA$, model 21X; tipping bucket rain gage Texas Eletronics ${ }^{\circledR}$, model TE525; temperature and relative humidity probe Vaisala ${ }^{\circledR}$, model HMP35C) located $550 \mathrm{~m}$ away from the field trial.

The treatments were arranged in a $3 \times 4$ factorial: three wheat (Triticum aestivum) genotypes (S1, S2 and MR1, commercial cultivars BRS Gralha-Azul, BRS Sabiá and BRS Pardela, respectively) and four $\mathrm{N}$ rates $(0,40,80$ and $120 \mathrm{~kg} / \mathrm{ha}$ ). The experimental design was randomized complete blocks, with four replicates, and both factors - genotypes and $\mathrm{N}$ rates - were randomly allocated within each block. Genotypes S1 and MR1 are classified as medium-maturing (115 to 130 days), while genotype S2 is early-maturing (< 110 days) (Bassoi et al. 2016). The levels of resistance to blast disease, following Goulart et al. (1991), are defined based on the percentage of wheat spikes with blast symptoms at the end of the cycle: resistant (R), 1 to $5 \%$; moderately resistant (MR), 6 to $25 \%$; moderately susceptible (MS), 26 to $50 \%$; susceptible (S), 51 to $75 \%$; and highly susceptible (HS), 76 to $100 \%$. Two genotypes, S1 and S2, are classified as susceptible, and genotype MR1 is classified as moderately resistant to wheat blast on spikes (Bassoi et al. 2016).

The $\mathrm{N}$ source was ammonium nitrate, and it was applied in top dressing during wheat tillering (Z25 stage; Zadoks et al. 1974). The rates of $N$ were chosen based on wheat crop fertilization in the main Brazilian wheat-producing regions, which have ranged from 20 to $140 \mathrm{~kg} / \mathrm{ha} \mathrm{N}$ (Cunha and Caierão 2014). The plots consisted of nine rows, $6.0 \mathrm{~m}$ in length, spaced $0.2 \mathrm{~m}$ apart $\left(10.8 \mathrm{~m}^{2}\right)$, and the seeding density was regulated to obtain about 300 plants per $\mathrm{m}^{2}$ for all genotypes. The sowing dates of the trials were April 16th and April 14th, in 2015 and 2016 crop seasons, respectively. Basal fertilization consisted of $22.4 \mathrm{~kg} / \mathrm{ha} \mathrm{N}, 42 \mathrm{~kg} / \mathrm{ha} \mathrm{P}_{2} \mathrm{O}_{5}$ and $60 \mathrm{~kg} /$ ha $\mathrm{K}_{2} \mathrm{O}$, applied during wheat sowing.

In each plot, wheat severity on spikes with typical disease symptoms (bleaching noticed above dark lesions formed in the rachis) was estimated visually aided by a diagrammatic scale containing 10 grades of severity ranging from 0 to $100 \%(0,3.5,7.5,21.5,30.5,44,57.5,68,86$ and $100 \%)$ (Maciel et al. 2013). A destructive sampling method was used to collect at least 60 spikes from two central wheat rows $0.5 \mathrm{~m}$ long, selected at random inside each plot, when the plants were on average in dough development (Z80 stage; Zadoks et al. 1974). Plot severity was recorded as the average proportion of diseased spikelets per spike, divided by the total number of spikes sampled, including those with zero severity (Paul et al. 2005). In addition, 50 healthy spikes (which were free from the disease) were sampled at random inside each plot and thrashed; the rachises were dried $\left(65^{\circ} \mathrm{C}\right.$ for $\left.48 \mathrm{~h}\right)$ and submitted to nutritional analyses (N, P, K, Ca, Mg, S, Zn, Mn, Fe, Cu and B) (Silva 2009). The additional aim of these analyses was to verify a possible correlation between rachis nutritional status and disease severity on spikes. Yield was determined by harvesting wheat plants at maturity ( $5 \mathrm{~m}$ in length) from seven center rows from each plot and recording the grain weight after adjusting the moisture content to $13 \%$.

Experimental data for each crop season (2015 and 2016), individually, were analyzed by the GENES $\AA$ statistical package (Cruz 2013). Analyses of models assumptions were 
performed: Lilliefors' test for normality, and Bartlett's test for homogeneity of variance. Skewness and kurtosis coefficients were also evaluated. According to these tests, no data transformation was needed. Since all assumptions required for analysis of variance (ANOVA) were met, the F-test was performed. When ANOVA was significant $(P \leq 0.05)$, the means of yield and blast severity were adjusted by linear and quadratic models of linear regression, using the SAEG® statistical package (Euclydes 1997). Coefficients of adjusted models were assessed by F-test $(P<0.001, P<0.01$ and $P<0.05)$ considering the mean square error of ANOVA. Finally, between two models with significant coefficients, the one with higher simple or multiple coefficient of determination $\left(\mathrm{r}^{2}\right.$ or $\mathrm{R}^{2}$, respectively) was chosen. The Tukey's test $(P \geq 0.05)$ was also used for multiple comparisons, considering yield and blast severity. Additionally, Pearson's correlation coefficient (r) was calculated (at significance levels of $P<0.001, P<0.01$ and $P<0.05$, individually for each genotype) between wheat blast severity and grain yield or the concentration of each nutrient (N, P, K, Ca, Mg, S, Zn, Mn, Fe, Cu and B) in the rachis.

\section{Experimental setting 2, Floresta trials}

Another experimental setting, in a third year, was established in Floresta $\left(23^{\circ} 35^{\prime} 26^{\prime \prime} \mathrm{S}, 52^{\circ} 04^{\prime} 22^{\prime \prime} \mathrm{W}\right.$; altitude of $\left.390 \mathrm{~m}\right)$, Paraná State, southern Brazil, and it was replicated during the 2017 crop season for two sowing dates: March 29th and April 18th. The climate of the region is humid subtropical, Cfa according to the Köppen classification (Köppen 1931). Daily meteorological variables (precipitation, temperature and relative humidity; Fig. 2) were recorded in an automatic weather station (equipped with: datalogger Campbell Scientific ${ }^{\circledR}$, model CR100; tipping bucket rain gage Campbell Scientific ${ }^{\circledR}$, model TB4; temperature and relative humidity probe Vaisala ${ }^{\circledR}$, model HMP35C) located $430 \mathrm{~m}$ away from the experiment.

The treatments were arranged in a $6 \times 3$ factorial: six wheat (T. aestivum) genotypes [S1, S2 and MR1 (all the same as the first experiment); MR2, MS1 and MS2, commercial cultivars BRS Graúna, BRS Tangará and BRS Sanhaço, respectively] and three $\mathrm{N}$ rates $(0,60$ and $120 \mathrm{~kg} / \mathrm{ha})$. The experimental design was randomized complete blocks, with three replicates, and both factors - genotypes and $\mathrm{N}$ rates - were randomly assigned to each block. In relation to the reaction to blast disease, genotypes S1 and S2 are classified as susceptible, MR1 and MR2 as moderately resistant, and MS1 and MS2 as moderately susceptible (Bassoi et al. 2016). With respect to phenology, genotypes S1, MR1, MS1 and MS2 are classified as medium-maturing (115 to 130 days), while genotypes S2 and MR2 are early-maturing ( $<110$ days) (Bassoi et al. 2016). The $\mathrm{N}$ source was urea, and it was applied in top dressing at the beginning of wheat tillering (Z22 stage; Zadoks et al. 1974).

The plots consisted of 13 rows, $4.0 \mathrm{~m}$ in length, spaced $0.17 \mathrm{~m}$ apart $\left(8.84 \mathrm{~m}^{2}\right)$, and the seeding density was regulated to obtain about 300 plants per $\mathrm{m}^{2}$ for all genotypes. Basal fertilization consisted of $60 \mathrm{~kg} / \mathrm{ha} \mathrm{P}_{2} \mathrm{O}_{5}$ and $60 \mathrm{~kg} / \mathrm{ha} \mathrm{K}_{2} \mathrm{O}$, applied during wheat sowing. Wheat blast on spikes was evaluated in the same way as described for the first experiment. Yield was determined by harvesting wheat plants at maturity ( $3 \mathrm{~m}$ in length) from 11 center rows from each plot and recording the grain weight after adjusting the moisture content to $13 \%$. Experimental data for each wheat crop (first and second), individually, were statistically analyzed, and the methods were the same as described for the experiment 1 , with the exception of regression analysis (which was not performed).

In both experiments (Londrina and Floresta environments), controls of weeds, insects and diseases were performed in accordance with regional technical recommendations for wheat crop (Cunha and Caierão 2014). However, wheat blast on spikes was not controlled by means of fungicide or other techniques. The presence or absence of blast on leaves was not evaluated or observed in the experiments. In addition, MoT strains occurring in these two regions of Paraná State are considered equivalent to each other, according to previous sampling and phenotyping performed by Castroagudín et al. (2015).

\section{Results}

\section{Londrina trials}

Wheat blast was not recorded during the 2016 crop season. In 2015, a significant interaction between $\mathrm{N}$ rate and genotype factors for blast severity was found (Table 1). Nitrogen fertilization increased blast severity on spikes of wheat genotype S1 (Fig. 3a). IThe greatest effect was observed with the rate of $80 \mathrm{~kg} / \mathrm{ha} \mathrm{N}$, which increased blast severity by $44.9 \%$ compared with the control treatment $(0 \mathrm{~kg} / \mathrm{ha} \mathrm{N})$.

Genotype MR1 was more resistant to wheat blast than S2 blast severity was $37.2,39.6$ and $26.9 \%$ lower in the $\mathrm{N}$ rates of 0,40 and $120 \mathrm{~kg} / \mathrm{ha}$, respectively (Fig. 3a). In turn, blast severity in MR1 was 37.4 and $45.7 \%$ lower than in S1 in the N rates of 40 and $80 \mathrm{~kg} / \mathrm{ha}$, respectively. Finally, genotypes S1 and S2 did not differ in blast severity (except for $\mathrm{N}$ rate of $80 \mathrm{~kg} / \mathrm{ha})$.

Nitrogen rate and genotype interaction was significant for grain yield in both seasons (Table 1). In most cases in 2015, yield was highest in S2 genotype than in S1 and MRI genotypes (Fig. 3b). Neither the MR1 nor S2 genotypes responded to $\mathrm{N}$ fertilization, but $\mathrm{S} 1$ genotype showed a decrease in yield by $24 \%$ for the treatment with $80 \mathrm{~kg} / \mathrm{ha} \mathrm{N}$ compared with the control treatment $(0 \mathrm{~kg} / \mathrm{ha} \mathrm{N})$ (Fig. $3 \mathrm{~b})$. The correlation 
Table 1 Summary of the analysis of variance of grain yield and blast severity for three wheat genotypes (S1, S2 and MR1) in the crop seasons of 2015 and 2016 in Londrina, Paraná (Brazil), in response to four nitrogen $(\mathrm{N})$ rates $(0,40,80$ and $120 \mathrm{~kg} / \mathrm{ha})$

\begin{tabular}{|c|c|c|c|c|c|}
\hline \multirow{3}{*}{$\begin{array}{l}\text { Source of } \\
\text { variation }\end{array}$} & \multirow[t]{3}{*}{$d f^{a}$} & \multicolumn{4}{|c|}{ Mean squares } \\
\hline & & \multicolumn{2}{|l|}{ Grain yield } & \multicolumn{2}{|c|}{ Blast severity } \\
\hline & & 2015 & 2016 & 2015 & $2016^{\mathrm{b}}$ \\
\hline Block & 3 & 52319 & 231896 & 117.3 & - \\
\hline Genotype (G) & 2 & $8667293^{* * * *}$ & $1289475^{* * *}$ & $481.2^{\text {**** }}$ & - \\
\hline $\mathrm{N}$ rate $(\mathrm{N})$ & 3 & $307445^{*}$ & $126244^{\mathrm{ns}}$ & $77.6^{*}$ & - \\
\hline $\mathrm{G} \times \mathrm{N}$ & 6 & $208170^{\circ}$ & $369725^{* *}$ & $53.5^{*}$ & - \\
\hline Error & 33 & 104373 & 96826 & 23.9 & - \\
\hline
\end{tabular}

Significance by F-test of main effects (genotype and $\mathrm{N}$ rate) and their interaction: ${ }^{\mathrm{ns}},{ }^{\mathrm{o}},{ }^{*},{ }^{* *}$ and ${ }^{* * *}=$ no significant, and significant at $P \leq 0.1,0.05,0.01$ and 0.001 , respectively

${ }^{\mathrm{a}} \mathrm{df}$, degrees of freedom; ${ }^{\mathrm{b}}$ There was no wheat blast in the 2016 crop season between yield and blast severity in genotype $\mathrm{S} 1$ was negative and highly significant $\left(\mathrm{r}=-0.90^{* * *}\right)$.

Considering all genotypes together, $\mathrm{N}$ rates did not affect grain yield in the 2016 crop season (Table 1), even in the absence of blast disease for all treatments. However, analyzing each genotype separately (Fig. 3c), the rates of 40 and $80 \mathrm{~kg} /$ ha $\mathrm{N}$ increased MR1 yield by 13.6 and $15.2 \%$, respectively, when compared with the control treatment $(0 \mathrm{~kg} / \mathrm{ha} \mathrm{N})$. On the other hand, the rate of $120 \mathrm{~kg} / \mathrm{ha} \mathrm{N}$ decreased $\mathrm{S} 2$ yield by $16 \%$. Finally, genotype $\mathrm{S} 1$ was not responsive to $\mathrm{N}$ fertilization.

In 2016, genotype MR1 had the highest yields in the $\mathrm{N}$ rates of 40 and $80 \mathrm{~kg} / \mathrm{ha}$ (5009 and $5078 \mathrm{~kg} / \mathrm{ha}$, respectively); and lowest yields were verified in the $\mathrm{N}$ rate of $120 \mathrm{~kg} / \mathrm{ha}$ for $\mathrm{S} 2(3821 \mathrm{~kg} / \mathrm{ha})$ and in the rates of 40 and $80 \mathrm{~kg} / \mathrm{ha}$ for S1 and S2 (averages of 4297 and $4369 \mathrm{~kg} / \mathrm{ha}$, respectively) (Fig. 3c).

The average yield from the 2015 crop season was $26 \%$ lower than that obtained for 2016 (Fig. 3b and c), which can be partially attributed to the blast disease, which took place only in 2015 (average of 26.3\%). There was a significant effect of $\mathrm{N}$ rates on nutrient concentration in the rachis only for $\mathrm{Ca}$ and $\mathrm{Mg}$ (Tables 2 and 3). Nitrogen rate increased $\mathrm{Ca}$ and $\mathrm{Mg}$ concentrations by $22 \%$ (average of the treatments with 40,80 and $120 \mathrm{~kg} / \mathrm{ha} \mathrm{N}$ ) and $29 \%$ (treatment with $80 \mathrm{~kg} / \mathrm{ha} \mathrm{N})$, respectively, when compared with the control treatment $(0 \mathrm{~kg} / \mathrm{ha} \mathrm{N})$. Genotype MR1 had the highest concentrations of $\mathrm{N}, \mathrm{P}, \mathrm{Mg}, \mathrm{Zn}$ (together with $\mathrm{S} 1$ ), Mn, Fe (together with $\mathrm{S} 1$ ) and $\mathrm{Cu}$. In turn, the highest concentrations of $\mathrm{K}, \mathrm{Ca}$ (together with S1) and S were obtained by genotype S2. In turn, lower concentrations of $\mathrm{N}, \mathrm{P}, \mathrm{Mg}$ and $\mathrm{Mn}$ were found for the genotypes $\mathrm{S} 1$ and $\mathrm{S} 2 ; \mathrm{K}$ and $\mathrm{S}$ for MR1; and $\mathrm{Zn}$ and $\mathrm{Cu}$ for S2. There was no difference among genotypes for B concentration in the rachis.

Pearson's correlation coefficients between blast severity on spikes and the concentration of each nutrient (N, P, K, Ca, Mg, $\mathrm{S}, \mathrm{Zn}, \mathrm{Mn}, \mathrm{Fe}, \mathrm{Cu}$ and $\mathrm{B}$ ) in the rachis was statistically significant only for $\mathrm{N}$ in genotype $\mathrm{S} 2\left(\mathrm{r}=0.59^{*}\right)$.

\section{Floresta trials}

Blast severity did not occur on wheat genotypes in the 2017 second-crop. In turn, $\mathrm{N}$ rate and genotype interaction was significant for blast severity during the 2017 first-crop (Table 4). In this crop, wheat blast severity was very high, averaging $51 \%$ overall (Figs. $4 \mathrm{a}$ ). The decreasing order of average blast severity in the six wheat genotypes was: MR2 $(80 \%)>\mathrm{S} 2(75 \%)>\mathrm{S} 1(57 \%)>\operatorname{MS} 2(52 \%)>\operatorname{MS} 1(32 \%)>$ MR1 (12\%). Genotype MR1 was the most resistant to wheat blast in the $\mathrm{N}$ rates of 60 and $120 \mathrm{~kg} / \mathrm{ha}$, with blast severities of 11 and $13 \%$, respectively (Fig. 4a). In turn, in the $\mathrm{N}$ rate of $0 \mathrm{~kg} / \mathrm{ha}, \mathrm{MR} 1$ and MS1 were more resistant, with an average of blast severity of $11.5 \%$. In most of genotype versus $\mathrm{N}$ rate combinations, MR2 and S2 were the most susceptible to wheat blast, since their blast severities were very high, that is, 59 and $48 \%, 91$ and $84 \%$, and 90 and $93 \%$ for the $\mathrm{N}$ rates of 0,60 and $120 \mathrm{~kg} / \mathrm{ha}$, respectively, and in most situations they were higher than those verified in the other genotypes (S1, MR1, MS1 and MS2).

The effect of $\mathrm{N}$ rates on blast severity on spikes was highly significant $(P \leq 0.001)$ for five out of six genotypes (except for MR1) in the 2017 first-crop (Table 4 and Fig. 4a). In most cases (except for genotype S1), there was no difference between 60 and $120 \mathrm{~kg} / \mathrm{ha} \mathrm{N}$ on increasing blast severity. On average, the rates of 60 and $120 \mathrm{~kg} / \mathrm{ha} \mathrm{N}$ increased blast severity by $84,53,330$ and $137 \%$ for genotypes S2, MR2, MS1 and MS2, respectively, when compared with the control treatment ( $0 \mathrm{~kg} /$ ha $\mathrm{N})$ (Fig. 4a).

The blast disease strongly impaired wheat yield (Fig. 3a and $b$ ). There were high negative correlations between blast severity and grain yield $\left(\mathrm{r}=-0.85^{* *},-0.84^{* *},-0.93^{* * *}\right.$, $-0.74^{*}$ and $-0.75^{*}$ for genotypes S1, S2, MR2, MS1 and MS2, respectively). The average yields for the 2017 firstcrop were 2198,1037 and $725 \mathrm{~kg} /$ ha for average blast severities of 30,56 and $68 \%$, respectively (for the treatments with 0 , 60 and $120 \mathrm{~kg} / \mathrm{ha} \mathrm{N}$, respectively). 

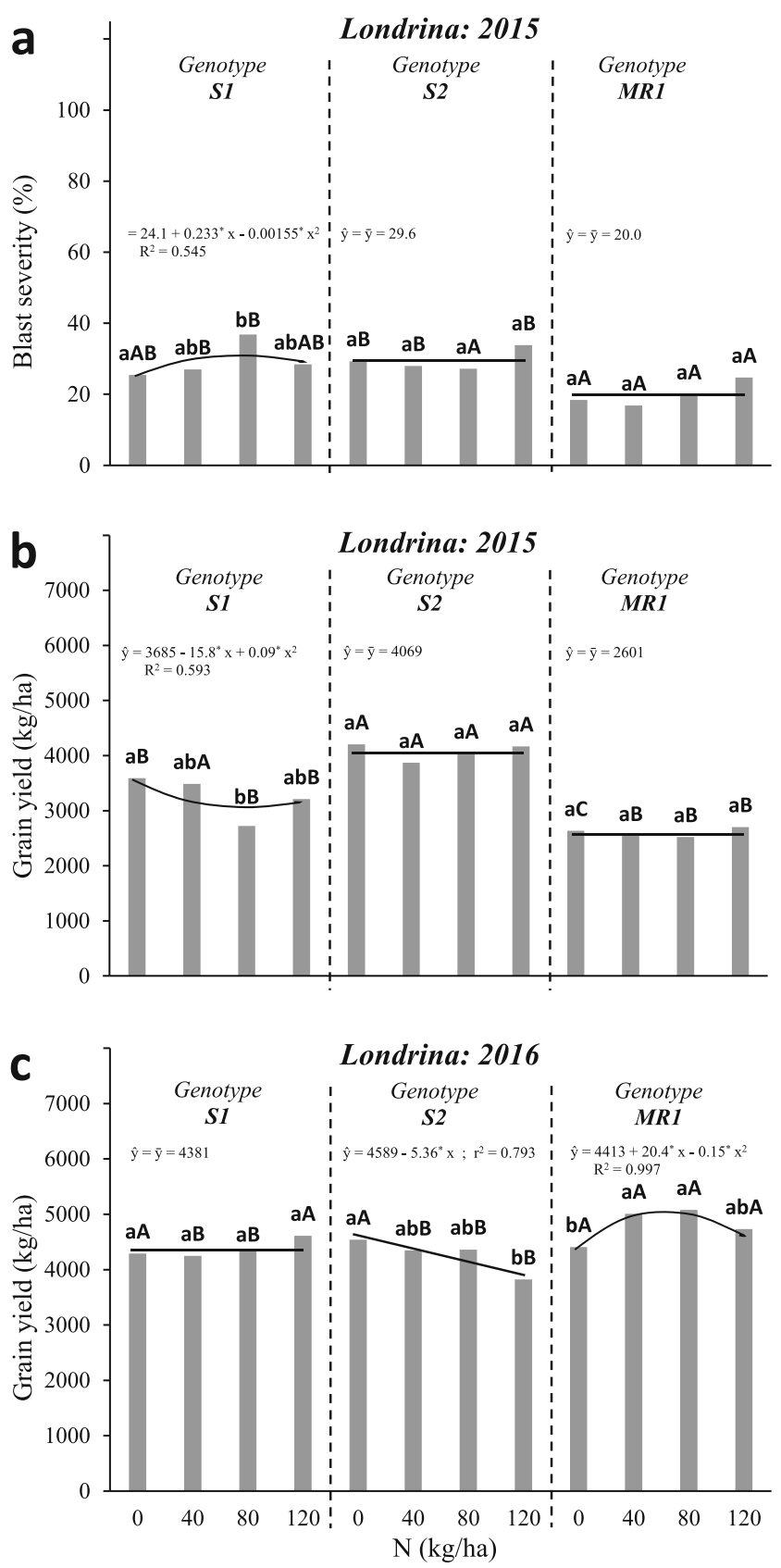

Fig. 1 The weather conditions [precipitation (P), relative humidity (RH) and average temperature $(\mathrm{T})$ of the air] during the crop seasons of 2015 (April 16th to August 20th $=127$ days) and 2016 (April 14th to September 8 th $=148$ days) are shown in $\mathbf{a}$ and $\mathbf{b}$, respectively

There was an interaction between $\mathrm{N}$ rate and genotype factors for grain yield during the 2017 first-crop (Table 4). Analyzing each genotype separately, the S1, MS1 and MS2 yields were lower at $120 \mathrm{~kg} / \mathrm{ha} \mathrm{N}$ than at $60 \mathrm{~kg} / \mathrm{ha} \mathrm{N}$ (Fig. 4b). On the other hand, the rate of $120 \mathrm{~kg} / \mathrm{ha} \mathrm{N}$ increased MR1 yield by $31 \%$ compared with the treatment with $60 \mathrm{~kg} / \mathrm{ha} \mathrm{N}$. In turn, there was no difference in grain yield of genotypes S2 and MR2 between treatments with 60 and $120 \mathrm{~kg} / \mathrm{ha} \mathrm{N}$, which were the least productive (average of $111 \mathrm{~kg} / \mathrm{ha}$ ). Finally, the
$\mathrm{N}$ rate of $0 \mathrm{~kg} / \mathrm{ha}$ resulted in higher wheat yields for all genotypes, with an overall average of $2198 \mathrm{~kg} / \mathrm{ha}$.

In the 2017 first-crop, the highest grain yields in the $\mathrm{N}$ rates of 60 and $120 \mathrm{~kg} / \mathrm{ha} \mathrm{N}$ were obtained by the genotypes MS1 ( $2467 \mathrm{~kg} / \mathrm{ha}$ ) and MR1 (2066 kg/ha), respectively (Fig. 4b). In turn, in the control treatment $(0 \mathrm{~kg} / \mathrm{ha} \mathrm{N})$ the most productive genotypes were S1, MR1 and MS1, with an average of $2700 \mathrm{~kg} / \mathrm{ha}$. In general, the genotypes S2 and MR2 were the least productive, with average grain yields of 1490, 130 and $92 \mathrm{~kg} / \mathrm{ha}$ in the $\mathrm{N}$ rates of 0,60 and $120 \mathrm{~kg} / \mathrm{ha}$, respectively. In addition, it was not possible to verify the effect of $\mathrm{N}$ rate on attainable grain yield, due to the confounding effect from the strong blast severity in this 2017 first-crop (Fig. 4a and b).

Blast severity on spikes did not occur in the 2017 secondcrop (Table 4). On average, the grain yield from this crop was almost three times higher than that from the first one (Fig. $4 \mathrm{~b}$ and c), despite the former not receiving any rain after the heading phenological stage (Fig. 2a and $b$ ).

In the 2017 second-crop, there was also a significant interaction between $\mathrm{N}$ rate and genotype factors for grain yield (Table 4). Nitrogen fertilization increased grain yield only in the genotypes MR1 and MR2 (except for $120 \mathrm{~kg} / \mathrm{ha} \mathrm{N}$ ) by 10.8 and $11.6 \%$, respectively (Fig. 4c). Considering each $\mathrm{N}$ rate individually, genotype MR1 was the most productive in the rates of 60 and $120 \mathrm{~kg} / \mathrm{ha} \mathrm{N}$, attaining 4104 and $4151 \mathrm{~kg} /$ ha, respectively, and S1 and MR1 had the higher yields at $\mathrm{N}$ rate of $0 \mathrm{~kg} / \mathrm{ha} \mathrm{N}$ (average of $3684 \mathrm{~kg} / \mathrm{ha}$ ). The lower grain yields were obtained by MR2 in the N rates of 0 and $120 \mathrm{~kg} / \mathrm{ha}$ (3061 and $3041 \mathrm{~kg} / \mathrm{ha}$, respectively), and by MR2 and MS2 at $\mathrm{N}$ rate of $60 \mathrm{~kg} / \mathrm{ha}$ (average of $3430 \mathrm{~kg} / \mathrm{ha}$ ).

\section{Discussion}

Results from our study, at least for one trial, suggest that wheat blast severity tends to increase with $\mathrm{N}$ fertilization under field conditions. To our knowledge, this is the first report from field studies about the effect of $\mathrm{N}$ fertilization on wheat blast on spikes. However, because out of two independent experiments where the disease occurred, a significant effect was observed in only one of them, a confirmation of a positive effect of $\mathrm{N}$ rate on wheat blast needs to be obtained in further studies in order to provide more conclusive information about this $\mathrm{N}$-wheat blast interaction.

Studies on rice blast showed that the application of $\mathrm{N}$ above the recommended rate for any given cultivar significantly increased blast disease (caused by $M$. oryzae) on rice leaves, while $\mathrm{N}$ treatments did not affect the blast incidence on collar rot or neck (Long et al. 2000). Kurschner et al. (1992) reported that while $\mathrm{N}$ fertilizer was essential for increasing rice grain yield, the blast severity on panicle also increased with the rate of $\mathrm{N}$ application. 
Table 2 Summary of the analysis of variance and multiple comparisons of macronutrient $(\mathrm{N}$, $\mathrm{P}, \mathrm{K}, \mathrm{Ca}, \mathrm{Mg}$ and $\mathrm{S}$ ) concentration in the rachis for three wheat genotypes (S1, S2 and MR1) in the crop season of 2015 in Londrina, Paraná (Brazil), in response to four nitrogen $(\mathrm{N})$ rates $(0,40,80$ and $120 \mathrm{~kg} / \mathrm{ha})$

\begin{tabular}{|c|c|c|c|c|c|c|c|}
\hline \multirow[t]{2}{*}{ Source of variation } & \multirow[t]{2}{*}{$d f^{a}$} & \multicolumn{6}{|c|}{ Mean squares } \\
\hline & & $\mathrm{N}$ & $\mathrm{P}$ & $\mathrm{K}$ & $\mathrm{Ca}$ & $\mathrm{Mg}$ & $\mathrm{S}$ \\
\hline Block & 3 & 3.71 & 0.050 & 2.66 & 0.0028 & 0.0086 & 0.116 \\
\hline Genotype (G) & 2 & $47.68^{* * *}$ & $1.071^{* * *}$ & $166.54^{* * * *}$ & $0.0164^{* *}$ & $0.0585^{* * * *}$ & $0.459^{* * * *}$ \\
\hline $\mathrm{N}$ rate $(\mathrm{N})$ & 3 & $2.51^{\mathrm{ns}}$ & $0.059^{\mathrm{ns}}$ & $3.63^{\mathrm{ns}}$ & $0.0405^{* * *}$ & $0.0266^{* *}$ & $0.039^{\mathrm{ns}}$ \\
\hline $\mathrm{G} \times \mathrm{N}$ & 6 & $3.31^{\mathrm{ns}}$ & $0.048^{\text {ns }}$ & $2.15^{\mathrm{ns}}$ & $0.0020^{\mathrm{ns}}$ & $0.0051^{\mathrm{ns}}$ & $0.025^{\text {ns }}$ \\
\hline Error & 33 & 3.60 & 0.049 & 2.76 & 0.0029 & 0.0060 & 0.024 \\
\hline \multirow[t]{2}{*}{ Factor } & Treatment & \multicolumn{6}{|c|}{ Macronutrient concentration $(\mathrm{g} / \mathrm{kg})$} \\
\hline & & $\mathrm{N}$ & $\mathrm{P}$ & $\mathrm{K}$ & $\mathrm{Ca}$ & $\mathrm{Mg}$ & $\mathrm{S}$ \\
\hline \multirow[t]{3}{*}{ Genotype (G) } & S1 & $8.8 \mathrm{~b}$ & $0.93 \mathrm{~b}$ & $13.6 \mathrm{~b}$ & $0.55 \mathrm{ab}$ & $0.41 \mathrm{~b}$ & $1.01 \mathrm{~b}$ \\
\hline & S2 & $8.6 \mathrm{~b}$ & $0.77 \mathrm{~b}$ & $17.0 \mathrm{a}$ & $0.59 \mathrm{a}$ & $0.41 \mathrm{~b}$ & $1.18 \mathrm{a}$ \\
\hline & MR1 & $11.7 \mathrm{a}$ & $1.28 \mathrm{a}$ & $10.5 \mathrm{c}$ & $0.53 \mathrm{~b}$ & $0.51 \mathrm{a}$ & $0.84 \mathrm{c}$ \\
\hline \multirow[t]{4}{*}{$\mathrm{N}$ rate $(\mathrm{N})$} & 0 & $9.1 \mathrm{a}$ & $0.90 \mathrm{a}$ & $13.0 \mathrm{a}$ & $0.48 \mathrm{~b}$ & $0.38 \mathrm{~b}$ & $0.93 \mathrm{a}$ \\
\hline & 40 & $9.8 \mathrm{a}$ & $1.05 \mathrm{a}$ & $13.8 \mathrm{a}$ & $0.55 \mathrm{a}$ & $0.46 \mathrm{ab}$ & $1.04 \mathrm{a}$ \\
\hline & 80 & $10.1 \mathrm{a}$ & $1.04 \mathrm{a}$ & $13.6 \mathrm{a}$ & $0.60 \mathrm{a}$ & $0.49 \mathrm{a}$ & $1.03 \mathrm{a}$ \\
\hline & 120 & $10.0 \mathrm{a}$ & $0.98 \mathrm{a}$ & $14.4 \mathrm{a}$ & $0.61 \mathrm{a}$ & $0.45 \mathrm{ab}$ & $1.05 \mathrm{a}$ \\
\hline
\end{tabular}

Significance by F-test of main effects (genotype and $\mathrm{N}$ rate) and their interaction: ${ }^{\mathrm{ns}},{ }^{*},{ }^{* *}$ and ${ }^{* * *}=$ no significant, and significant at $P \leq 0.05,0.01$ and 0.001 , respectively. Within a factor (genotype or $\mathrm{N}$ rate), means followed by the same letter are not significantly different at $P>0.05$ according to Tukey's test

${ }^{\mathrm{a}} \mathrm{df}$, degrees of freedom
The physiological mechanism of $\mathrm{N}$ effect on blast disease is not well understood. Ballini et al. (2013) showed that a phenomenon called nitrogen-induced susceptibility (NIS) affects the resistance of rice and wheat to blast fungus (M. oryzae) infection on leaves. This finding reveals that $\mathrm{N}$ partially breaks down resistance triggered by the Pil gene,
Table 3 Summary of the analysis of variance and multiple comparisons of micronutrient ( $\mathrm{Zn}, \mathrm{Mn}, \mathrm{Fe}, \mathrm{Cu}$ and $\mathrm{B}$ ) concentration in the rachis for three wheat genotypes (S1, S2 and MR1) in the crop season of 2015 in Londrina, Paraná (Brazil), in response to four nitrogen $(\mathrm{N})$ rates $(0,40,80$ and $120 \mathrm{~kg} / \mathrm{ha})$

\begin{tabular}{|c|c|c|c|c|c|c|}
\hline \multirow[t]{2}{*}{ Source of variation } & \multirow[t]{2}{*}{$\mathrm{df}^{\mathrm{a}}$} & \multicolumn{5}{|c|}{ Mean squares } \\
\hline & & $\mathrm{Zn}$ & $\mathrm{Mn}$ & $\mathrm{Fe}$ & $\mathrm{Cu}$ & $\mathrm{B}$ \\
\hline Block & 3 & 206 & 267 & 1064 & 0.72 & 24.5 \\
\hline Genotype (G) & 2 & $1814^{* * * *}$ & $1668^{* * * *}$ & $1566^{* * * *}$ & $34.44^{* * *}$ & $11.6^{\mathrm{ns}}$ \\
\hline $\mathrm{N}$ rate $(\mathrm{N})$ & 3 & $90^{\mathrm{ns}}$ & $22^{\mathrm{ns}}$ & $687^{\mathrm{ns}}$ & $0.73^{\mathrm{ns}}$ & $16.4^{\mathrm{ns}}$ \\
\hline $\mathrm{G} \times \mathrm{N}$ & 6 & $22^{\mathrm{ns}}$ & $43^{\mathrm{ns}}$ & $546^{\mathrm{ns}}$ & $0.78^{\mathrm{ns}}$ & $5.5^{\mathrm{ns}}$ \\
\hline Error & 33 & 75 & 64 & 273 & 0.76 & 7.6 \\
\hline \multirow[t]{2}{*}{ Factor } & \multirow[t]{2}{*}{ Treatment } & \multicolumn{5}{|c|}{ Micronutrient concentration $(\mathrm{mg} / \mathrm{kg})$} \\
\hline & & $\mathrm{Zn}$ & $\mathrm{Mn}$ & $\mathrm{Fe}$ & $\mathrm{Cu}$ & $\mathrm{B}$ \\
\hline \multirow[t]{3}{*}{ Genotype (G) } & S1 & $38.5 \mathrm{a}$ & $52.1 \mathrm{~b}$ & $113 \mathrm{ab}$ & $2.37 \mathrm{~b}$ & $3.73 \mathrm{a}$ \\
\hline & $\mathrm{S} 2$ & $24.0 \mathrm{~b}$ & $48.7 \mathrm{~b}$ & $106 \mathrm{~b}$ & $1.30 \mathrm{c}$ & $5.33 \mathrm{a}$ \\
\hline & MR1 & $44.8 \mathrm{a}$ & $67.8 \mathrm{a}$ & $126 \mathrm{a}$ & $4.20 \mathrm{a}$ & $4.03 \mathrm{a}$ \\
\hline \multirow[t]{4}{*}{$\mathrm{N}$ rate $(\mathrm{N})$} & 0 & $34.0 \mathrm{a}$ & $56.9 \mathrm{a}$ & $109 \mathrm{a}$ & $2.27 \mathrm{a}$ & $3.04 \mathrm{a}$ \\
\hline & 40 & $38.3 \mathrm{a}$ & $57.7 \mathrm{a}$ & $125 \mathrm{a}$ & $2.64 \mathrm{a}$ & $4.19 \mathrm{a}$ \\
\hline & 80 & $32.9 \mathrm{a}$ & $54.8 \mathrm{a}$ & $116 \mathrm{a}$ & $2.79 \mathrm{a}$ & $4.36 \mathrm{a}$ \\
\hline & 120 & $37.9 \mathrm{a}$ & $55.3 \mathrm{a}$ & $110 \mathrm{a}$ & $2.80 \mathrm{a}$ & $5.89 \mathrm{a}$ \\
\hline
\end{tabular}

Significance by F-test of main effects (genotype and $\mathrm{N}$ rate) and their interaction: ${ }^{\mathrm{ns}},{ }^{*},{ }^{* *}$ and ${ }^{* * *}=$ no significant, and significant at $P \leq 0.05,0.01$ and 0.001 , respectively. Within a factor (genotype or $\mathrm{N}$ rate), means followed by the same letter are not significantly different at $P>0.05$ according to Tukey's test

${ }^{\mathrm{a}} \mathrm{df}$, degrees of freedom 
Table 4 Summary of the analysis of variance of grain yield and blast severity for six wheat genotypes (S1, S2, MR1, MR2, MS1 and MS2) from two crops (first sowing date: March 29th; second sowing date: April 18th) in the 2017 season in Floresta, Paraná (Brazil), in response to three nitrogen $(\mathrm{N})$ rates $(0,60$ and $120 \mathrm{~kg} / \mathrm{ha})$

\begin{tabular}{|c|c|c|c|c|c|}
\hline \multirow[t]{3}{*}{ Source of variation } & \multirow[t]{3}{*}{$\mathrm{df}^{\mathrm{a}}$} & \multicolumn{4}{|l|}{ Mean squares } \\
\hline & & \multicolumn{2}{|l|}{ Grain yield } & \multicolumn{2}{|l|}{ Blast severity } \\
\hline & & 2017 first-crop & 2017 second-crop & 2017 first-crop & 2017 second-crop \\
\hline Block & 2 & 415568 & 3002067 & 207.2 & - \\
\hline Genotype (G) & 5 & $4795282^{* * *}$ & $817599^{* * * *}$ & $5916.0^{* * * *}$ & - \\
\hline $\mathrm{N}$ rate $(\mathrm{N})$ & 2 & $10845920^{\text {**** }}$ & $289030^{* * *}$ & $6712.6^{* * * *}$ & - \\
\hline $\mathrm{G} \times \mathrm{N}$ & 10 & $476021^{* * * *}$ & $32432^{* * * *}$ & $475.0^{* *}$ & - \\
\hline Error & 34 & 13104 & 1284 & 151.8 & - \\
\hline
\end{tabular}

Significance by F-test of main effects (genotype and $\mathrm{N}$ rate) and their interaction: ${ }^{*},{ }^{* *}$ and ${ }^{* * *}=$ significant at $P \leq$ $0.05,0.01$ and 0.001 , respectively

${ }^{\mathrm{a}} \mathrm{df}$, degrees of freedom; ${ }^{\mathrm{b}}$ There was no wheat blast in the 2017 second-crop and cytological analysis indicates that high $\mathrm{N}$ does not affect fungus penetration, whereas it does increase its growth inside the plant. Recently, Debona et al. (2012) and Rodrigues et al. (2017) reported that wheat resistance to blast disease was associated with control of the production of reactive oxygen species (ROS), favoring host defense mechanisms against MoT infection on leaves and rachis of wheat. According to these authors, a more efficient antioxidative system (that removes the excess ROS generated during the infection process prevents the cellular damage caused by MoT. According to Gupta et al. (2011), the pathway hydroxylamine-mediated nitric oxide (NO) production is involved in the regulation of the levels of ROS. These authors reported that, upon pathogen infection $\mathrm{NO}$ is likely to act as a signal that is required to induce plant defense mechanisms. In turn, Espunya et al. (2012) mentioned that S-Nitrosoglutathione is a mobile reservoir of $\mathrm{NO}$ and an important player in defense responses to pathogen attack in plants, acting synergistically with classic hormones involved in plant defense (particularly salicylic acid and jasmonic acid) to activate gene response at local and systemic sites. Considering that nitrate reductase (NR) is the main production pathway for $\mathrm{NO}$ in plants, and this enzyme requires nitrite
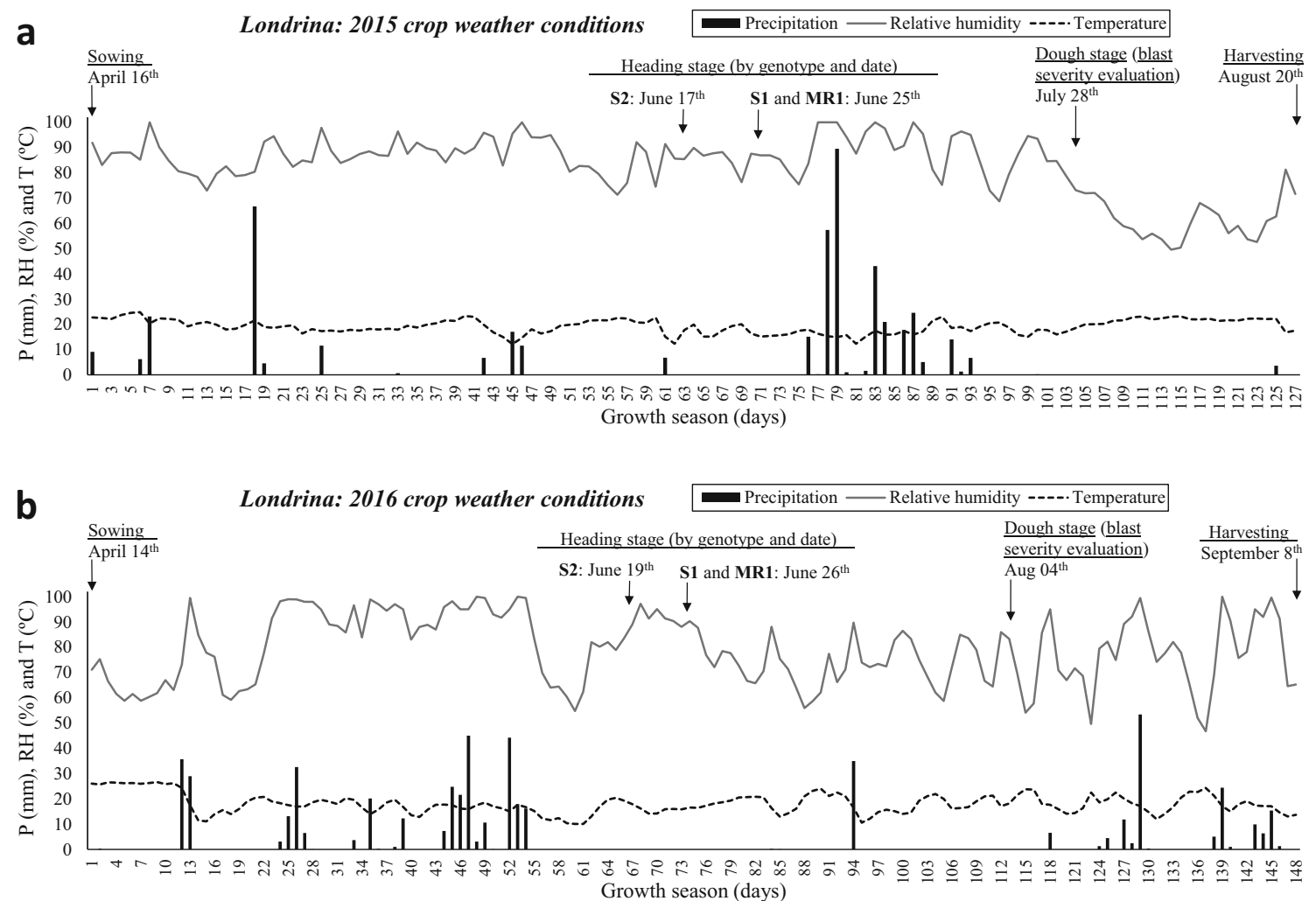

Fig. 2 The weather conditions [precipitation (P), relative humidity (RH) and average temperature (T) of the air] during the first (March 29th to August $1 \mathrm{st}=126$ days) and second (April 18th to August 25th $=130$ days) crop seasons are shown in $\mathbf{a}$ and $\mathbf{b}$, respectively 

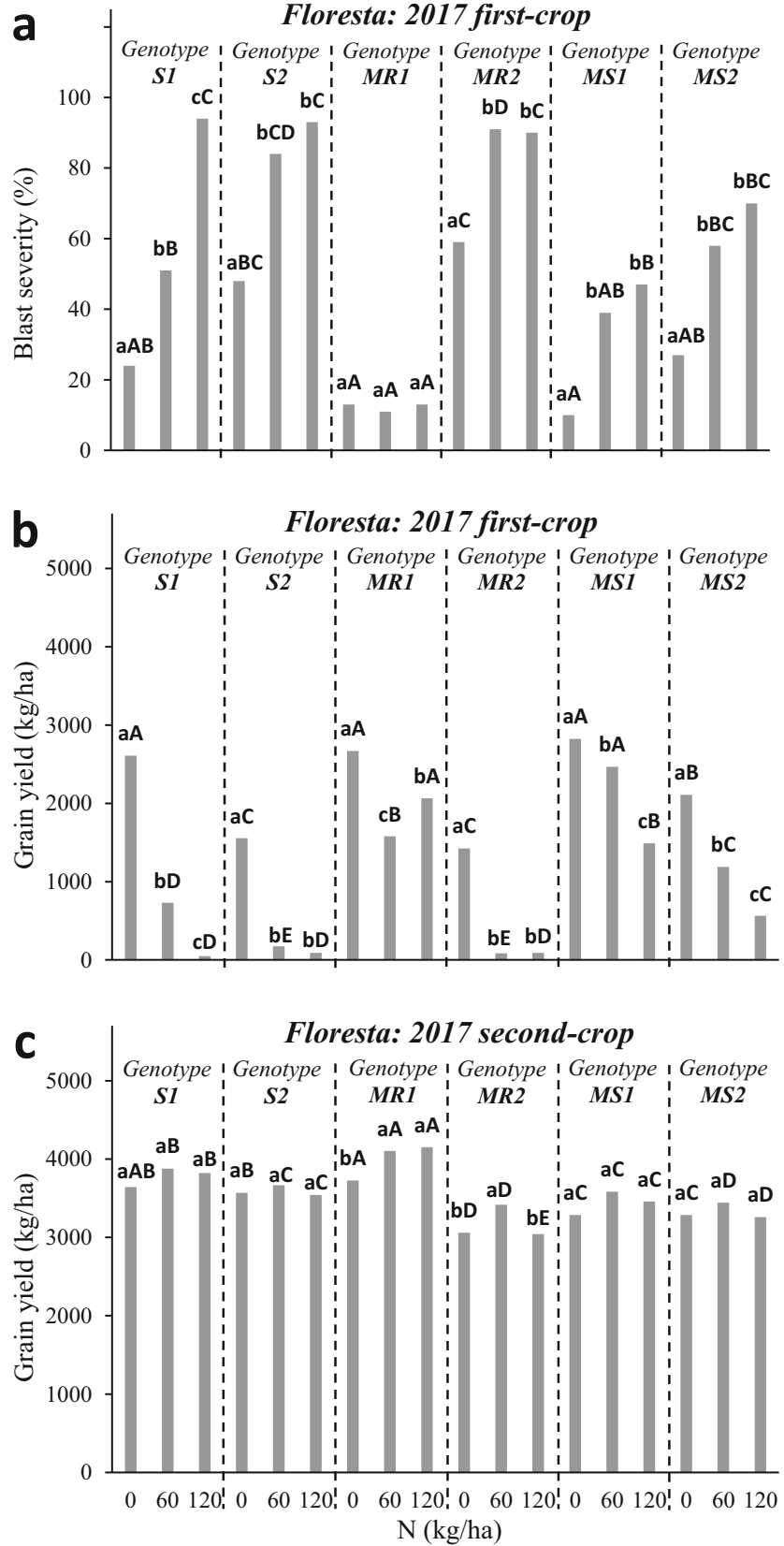

Fig. 3 Blast severity on spikes and grain yield from three wheat genotypes (S1, S2 and MR1) fertilized with four rates of $\mathrm{N}(0,40,80$ and $120 \mathrm{~kg} / \mathrm{ha}$ ), in the crop seasons of 2015 (a and b) and 2016 (c) in Londrina, Paraná (Brazil). Individually for each crop season and each wheat genotype, columns comparing $\mathrm{N}$ rates followed by the same lowercase letter do not differ significantly (Tukey's test, $P \geq 0.05$ ). Individually for each crop season and each $\mathrm{N}$ rate, columns comparing wheat genotypes followed by the same capital letter do not differ significantly. Above the histograms, there are regression equations adjusted as a function of $\mathrm{N}$ rates, individually for each wheat genotype. Note: there was no blast disease in the crop season of 2016

levels to be in excess of the substrate nitrate (Procházková et al. 2014), $\mathrm{N}$ fertilization has an indirect effect on this plant defense mechanism, being able to inhibit it, because $\mathrm{N}$ fertilizers applied to the soil are microbiologically transformed generating nitrate and/or ammonium, which are the $\mathrm{N}$-ions uptaken by the plants.

Another possibility for increased blast severity in response to $\mathrm{N}$ rates is the indirect effect of $\mathrm{N}$ on the disease via further development of the plant canopy. Hence, large canopies with high shoot density may be more favorable to spore transfer and pathogen infection than sparse canopies. For example, $\mathrm{N}$ has been shown to increase the severity of Fusarium head blight in wheat spikes, and it has been attributed to the result of an $\mathrm{N}$-induced increase in canopy size, leading to an altered microclimate (which remains humid over a longer period of time after rain or after dew periods), that is more conducive to infectious process (Lemmens et al. 2004). This change in microclimate, when plants grow larger and denser, can decrease air circulation and increase water holding capacity, both of which being effective to increase wetness duration, that is a favorable condition to MoT sporulation and infection. Additionally, this higher humidity within the canopy can also delay crop ripening, and the rachis may remain receptive to fungal infection for a longer period of time.

The weather conditions were key for blast disease development in the 2015 crop season in Londrina, where there was an extended period of rainfall (76th to 93rd days at the growth season; total of $298.4 \mathrm{~mm}$ during 18 days) after the heading stage, associated with an average temperature of $17^{\circ} \mathrm{C}$ (ranging from 12.4 to $23.1^{\circ} \mathrm{C}$ ) (Fig. 1a), resulting in medium levels of blast severity. On the other hand, in the 2016 crop season, the absence of wheat blast disease can be partially explained by the insufficient amount of rain (total of $35.3 \mathrm{~mm}$ during 40 days) from the last heading to dough stage (74th to 113th days at the growth season, respectively; Fig. 1b), although the average temperature was similar to that in the previous winter crop season.

Wheat blast disease was null during 2017 second-crop in Floresta environment, because there was no rain after the heading stage (Fig. 2b). In other words, the absence of free water on the rachis did not allow infection of MoT in this plant tissue, preventing the effects of $\mathrm{N}$ rate and genotype treatments on blast disease. In turn, in 2017 first-crop there was a significant amount of rain (total of $89.2 \mathrm{~mm}$ during 36 days; Fig. 2a) from the first heading to dough stage (64th to 99th days at the growth season, respectively), and the wheat crop was highly infected by the disease, which can be considered a blast epidemic crop, since the wheat yield was highly impaired.

Differential responses to blast disease among wheat genotypes are attributed to different associations between the postheading period (from heading to dough stage, when the rachis tissue is more vulnerable to MoT infection) and the respective weather conditions, resulting in the erratic nature of blast epidemics (Cardoso et al. 2008; Cruz et al. 2016; Cruz and Valent 2017). For example, in 2017 first-crop experiment, the wheat heading dates of genotypes S2 (May 31st), S1 and MR2 (June 3rd) were followed by a rainy period (27.4, 19.6 

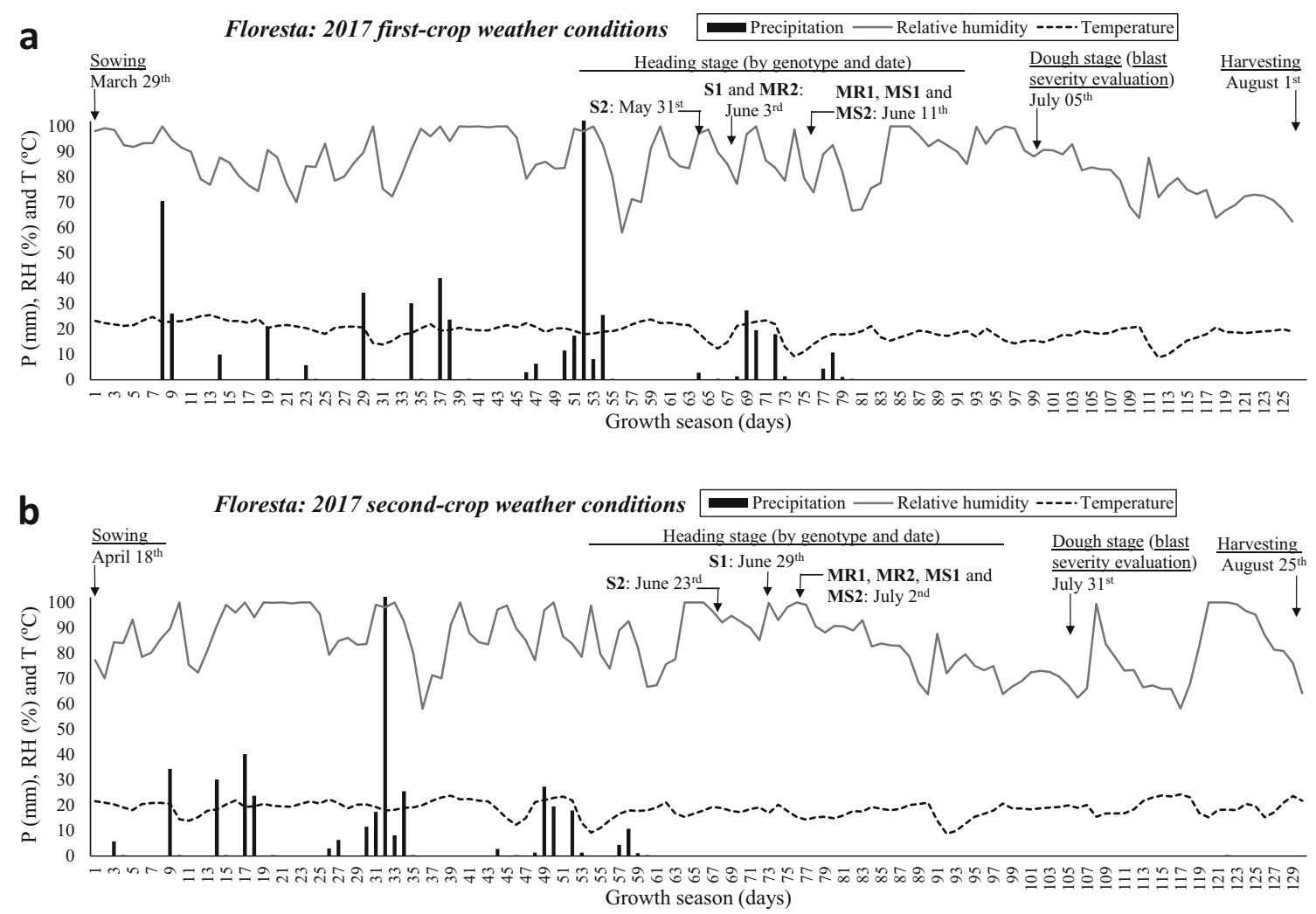

Fig. 4 Blast severity on spikes and grain yield from six wheat genotypes (S1, S2, MR1, MR2, MS1 and MS2) fertilized with three rates of $\mathrm{N}(0,60$ and $120 \mathrm{~kg} / \mathrm{ha}$ ), in two crops in 2017 (First: a and b; Second: c) in Floresta, Paraná (Brazil). Individually for each crop and each wheat genotype, columns comparing $\mathrm{N}$ rates followed by the same lowercase letter do not differ significantly (Tukey's test, $P \geq 0.05$ ). Individually for each crop and each $\mathrm{N}$ rate, columns comparing wheat genotypes followed by the same capital letter do not differ significantly. Note: there was no blast disease in the second crop of the 2017 season

To date, prescription of $\mathrm{N}$ fertilization for wheat has not considered the $\mathrm{N}$-wheat blast interaction in tropical and subtropical agricultural regions where this disease is endemic. Since $\mathrm{N}$ can modify blast severity, a cost-benefit ratio should be considered before deciding the $\mathrm{N}$ fertilizer rate to be recommended to wheat crop. Therefore, the findings from these field studies have applied significance for farmers, since $\mathrm{N}$ fertilization is widely used in most wheat crop systems.

In conclusion, $\mathrm{N}$ fertilization can increase wheat blast severity when weather conditions are favorable for MoT infection in the rachis. For improving the management of this disease, $\mathrm{N}$ fertilization technique should be improved, and suitable sowing date chosen, in order to reduce the likelihood of weather conditions favorable for wheat blast development during the postheading phenological stage. However, its implementation requires accurate information on the probability of disease infection based on historical records and predictive models.

Acknowledgements This research was supported by Brazilian Agricultural Research Corporation (Embrapa), Agricultural Research Institute of Paraná (IAPAR), Fundação Meridional de Apoio à Pesquisa Agropecuária, and COCAMAR Cooperativa Agroindustrial. We thank Fernando Portugal, Danilo Nassar, Caio Mazeto, Leandro Borsato, and Márcio Nunes for their technical assistance. Finally, the authors are 
grateful to Dr. Leandro Dallagnol who handled our submission and the three anonymous reviewers for their valuable questions, comments and suggestions, which improved the final quality of this work.

\section{References}

Ballini E, Nguyen TTT, Morel JB (2013) Diversity and genetics of nitrogen-induced susceptibility to the blast fungus in rice and wheat. Rice 6:1-32

Bassoi MC, Riede CR, Campos LAC, Foloni JSS, Nascimento Júnior A, Garbuglio DD, Arruda KM (2016) Cultivares de trigo e triticale Embrapa e Iapar. Londrina, Brazil: Embrapa Soja

Callaway E (2016) Devastating wheat fungus appears in Asia for first time. Nature 532:421-422

Cardoso CAA, Reis EM, Moreira EN (2008) Development of a warning system for wheat blast caused by Pyricularia grisea. Summa Phytopathologica 34:216-221

Castroagudín VL, Ceresini PC, Oliveira SC, Reges JTA, Maciel JLN, Bonato ALV, Dorigan AF, McDonald BA (2015) Resistance to QoI fungicides is widespread in Brazilian populations of the wheat blast pathogen Magnaporthe oryzae. Phytopathology 105:284-294

Cruz CD (2013) GENES - a software package for analysis in experimental statistics and quantitative genetics. Acta Scientiarum. Agronomy 35:271-276

Cruz CD, Valent B (2017) Wheat blast disease: danger on the move. Tropical Plant Pathology 42:210-222

Cruz MFA, Maciel JLN, Prestes AM, Bombonatto EAS, Pereira JF, Consoli L (2009) Caracterização genética e fenotípica de isolados de Pyricularia grisea do trigo. Tropical Plant Pathology 34:393-401

Cruz CD, Magarey RD, Christie DN, Fowler GA, Fernandes JM, Bockus WW, Valent B, Stack JP (2016) Climate suitability for Magnaporthe oryzae Triticum pathotype in the United States. Plant Disease 100: 1979-1987

Cunha GR, Caierão E (2014) Informações técnicas para trigo e triticale safra 2015. Brasília, Brazil. Embrapa

Debona D, Rodrigues FA, Rios JA, Nascimento KJT (2012) Biochemical changes in the leaves of wheat plants infected by Pyricularia oryzae. Phytopathology 102:1121-1129

Espunya MC, De Michele R, Gómez-Cadenas A, Martínez MC (2012) SNitrosoglutathione is a component of wound- and salicylic acidinduced systemic responses in Arabidopsis thatiana. Journal of Experimental Botany 63:3219-3227

Euclydes RF (1997) Manual de utilização do programa SAEG: Sistema para Análises Estatísticas e Genéticas. $1^{\text {st }}$ Ed. Viçosa, Brazil. Viçosa Federal University Press

Goulart ACP, Paiva FA, Colman OP (1991) Reação de cultivares de trigo (Triticum aestivum L.) à brusone (Pyricularia oryzae Cav) em condições de campo. In: VII Reunião da Comissão Centro-Sul Brasileira de Pesquisa de Trigo, Curitiba, PR. Resultados de pesquisa com trigo - 1990. Dourados: Embrapa. p. 118-120

Goulart ACP, Sousa PG, Urashima AS (2007) Danos em trigo causados pela infecção de Pyricularia grisea. Summa Phytopathologica 33: 358-363

Gupta KJ, Fernie AR, Kaiser WM, van Dongen JT (2011) On the origins of nitric oxide. Trends in Plant Science 16:160-168
Huber DM, Thompson IA (2007) Nitrogen and plant disease. In: Datnoff LE, Elmer WH, Huber DM (Eds.) Mineral Nutrition and Plant Disease. Saint Paul, USA. APS Press. pp. 31-44

Kohli MM, Mehta YR, Guzman E, De Viedma L, Cubilla LE (2011) Pyricularia blast - a threat to wheat cultivation. Czech Journal of Genetics and Plant Breeding 47:130-134

Köppen W (1931) Grundriss der Klimakunde. 1st Ed. Berlin, German. Walter de Gruyter

Kurschner E, Bonman JM, Garrity DP, Tamisin MM, Pabale D, Estrada BA (1992) Effects of nitrogen timing and split application on blast disease in upland rice. Plant Disease 76:384-389

Lemmens M, Haim K, Lew H, Ruckenbauer P (2004) The effect of nitrogen fertilization on Fusarium head blight development and deoxynivalenol contamination in wheat. Journal of Phytopathology 152:1-8

Lima MIPM (2004) Giberela ou brusone? Orientações para a identificação correta dessas enfermidades em trigo e cevada. Documentos 51. Embrapa Trigo

Long DH, Lee FN, TeBeest DO (2000) Effect of nitrogen fertilization on disease progress of rice blast on susceptible and resistant cultivars. Plant Disease 84:403-409

Maciel JLN, Danelli ALD, Boaretto C, Forcelini CA (2013) Diagrammatic scale for the assessment of blast on wheat spikes. Summa Phytopathologica 39:162-166

Mur LAJ, Simpson C, Kumari A, Gupta AK, Gupta KJ (2016) Moving nitrogen to the centre of plant defence against pathogens. Annals of Botany 119:703-709

Paul PA, El-Allaf SM, Lipps PE, Madden LV (2005) Relationships between incidence and severity of Fusarium head blight on winter wheat in Ohio. Phytopathology 95:1049-1060

Procházková D, Haisel D, Pavlíková D (2014) Nitric oxide biosynthesis in plants - the short overview. Plant, Soil and Environment 60:129 134

Rodrigues FA, Rios JA, Debona D, Aucique-Pérez CE (2017) Pyricularia oryzae-wheat interaction: physiological changes and disease management using mineral nutrition and fungicides. Tropical Plant Pathology 42:223-229

Sadat MA, Choi J (2017) Wheat blast: a new fungal inhabitant to Bangladesh threatening world wheat production. The Plant Pathology Journal 33:103-108

Silva FC (Ed.) (2009) Manual de análises químicas de solos, plantas e fertilizantes. $2^{\text {nd }}$ Ed. Brasília, Brazil. Embrapa Informação Tecnológica

Veresoglou SD, Barto EK, Menexes G, Rillig MC (2013) Fertilization affects severity of disease caused by fungal plant pathogens. Plant Pathology 62:961-969

Zadoks JC, Chang TT, Konzak CF (1974) A decimal code for the growth stages of cereals. Weed Research 14:415-421

Publisher's note Springer Nature remains neutral with regard to jurisdictional claims in published maps and institutional affiliations. 